\title{
The Techniques Teaching Vocabulary with BCCT Based Learning in Islamic Kindergarten Samarinda (A Case Study at Al-Azhar Syifa Budi Kindergarten)
}

\author{
Hasbi Sjamsir \\ Faculty of Teacher and Education \\ Mulawarman University \\ Samarinda, East Borneo \\ hasbisjamsir@fkip.unmul.ac.id
}

\author{
Dian Anggriayani \\ Faculty of Teacher and Education \\ Mulawarman University \\ Samarinda, East Borneo \\ basrah01@gmail.com
}

\author{
Putri Mutia Ishaq \\ Niko Kindergarten Samarinda \\ Dinas Pendidikan Kota Samarinda \\ Samarinda, East Borneo \\ putri.muntaha.ishaq@gmail.com
}

\begin{abstract}
The purpose of this study is to know the teaching techniques used by teachers in teaching English vocabulary for 5-6 years old students of Al-Azhar Syifa Budi Kindergarten Samarinda based on BCCT learning model in the 2016/2017 academic year. The design of this study was descriptive qualitative, the focus of the study was techniques which was used by teachers. The subject of the study was the teachers of the $B$ class in Al-Azhar Kindergarten. The researcher conducted two instruments which were used to interview and observation. Data analysis using data reduction, data display, and conclusion drawing/verification. The findings showed that there are seven teaching techniques used by teachers in teaching English vocabulary for 5-6 years old, there are disciplinary, using media, using song, real object, show and tell, games and playing, and giving the reward. In applying the teaching techniques, the teachers always attempt to make the class fun for every young learner.
\end{abstract}

Keywords-BCCT based learning, teaching techniques, very young learner, vocabulary

\section{INTRODUCTION}

A successful implementation of language policy need the involvement of teacher trainers and teachers in the language teaching process. The younger children learn better as the assumption 'the younger the better' strengthened the beliefs. In that term, a longer exposure leads to greater proficiency by the end of the language education process [1]. On the other hand, there is an agreement that young learners have some advantages over the older ones who start later and they learn languages in a different way than older learners. According to Paradis, there are several advantages of an early start. First, since they can rely on natural acquisition processes, young learners acquire languages with greater ease, especially the sound system, and develop implicit competence [2]. They are undeniably better at acquiring the sounds and rhythms of the target language.

A teacher has the important role in the classroom. According to Brown, teaching is a superior job and a demanding job [3]. The task includes creating and modifying the approaches, strategies, syllabus, technique, and activities to adopt and maximize the learning of the class as well as of most of its dual. In teaching, a teacher should make students know or understand something by giving instruction and guiding how the learners to get the knowledge. Not only that, a teacher also has a job to introduce students to the nature of reality, how they have a certain attitude, and create an awareness of their responsibility as members trained in the art of critical thinking.

According to Sheahan, the teacher was responsible for identifying what classroom instruction methods that are effective for students [4]. Since every student did not learn and retain information in the same way, the teacher should come up with the variety of techniques to be used in the classroom so all students could get the benefit of the lesson. The age of students is also a thing that needs to be considered when selecting an appropriate technique.

Nisak stated that to get a good result in teaching for the very young learner, the teacher must be creative [5]. The teacher should create many kinds of teaching media and technique, such as songs, stories, games, pictures, and cards. Students needed that because very young learners have their own characteristics-biological, cognitive, personality and also social characteristic. Moreover, for the very young learners, who categorized of under 6 years old. Very young learners still had a strong natural character in doing their everyday activities. They are different from an adult. The teacher cannot teach them the way they teach elementary or high school, because the very young learners are still developing. They learned as they play.

Cameron said that children are easier to lose their interest and them less able to keep themselves motivated [6]. To make the very young learner happy and have willing attention, the teacher should consider the choice of suitable techniques or steps to be applied. The teacher should be smart in selecting the teaching techniques that can make students become active and fun so the teaching and learning process can be more interesting. Although, there is no one best approach because the circumstances and needs of ESL students vary so greatly. However, there are various methods and techniques for teaching foreign languages, the most appropriate one for young learners is the TPR method [7].

In kindergarten, all of the material should be taught with interesting way. Many kindergartens also use BCCT model as their strategies to make students easy to connect with every subject that has related purposes will be combined in one theme. For example, 'My Family' theme. So in this theme, students will learn about their family member are. Like father, mother, sister, and brother. After that, the student will learn to count how many sister or brother they 
have. Also, the teacher will teach them how to call part of their family in English and ask students to draw their family in a paper and coloring it with many colors. In this theme, the students can learn about Indonesian language, English language, math and also they learn how to drawing. But the students just know they are playing and enjoy that.

According to the student database in Al-Azhar Syifa Budi Kindergarten Samarinda, the students are from 3 to 5 year old. There are two levels in this kindergarten which are A class and B class. A class consists of 3 to 4 -year-old students while B class consists of 4 until 5-year-old students. AlAzhar is one of the kindergartens in Samarinda that teach their students about English. The students are familiarized with English instructions and the teacher always repeat and translate it into Indonesian language, so the student sooner or later will understand about these instructions. One of the interesting things about this school is the students in B class are common with English instructions and also easy and fun to learn English as their foreign language. Besides the students is really young and easy to lose their interest.

According to Musfiroh when children are 5 years old, the children are able to remember and use more than 3000 words [8]. The word that children have known including verb, adverb, noun, adjective, and pronoun. In the same hand, Osborn, White, and Bloom mentioned that when children are 5 years old [9]. children's intelligence capacity has reached $50 \%$. And All of the memories that they have will affect their lives. Maybe this is one of the reasons why the students can learn English quickly. But it cannot happen without good treatment from the teacher in teaching and learning process with the right teaching technique.

\section{LITERATURE REVIEW}

\section{A. Characteristic of Very Young Learners}

Very young learners use active learning for their learning process by exploring immediate settings [10]. They create their own learning by engaging with their environment. Vygotsky states that children construct knowledge through social interaction [11]. Children acquire knowledge through interaction with other people through the Zone of Proximal Development (ZPD). ZPD helps children to reach their optimum capacity to solve problems with assistance. By this concept, children learn with the help or guidance of an adult or more proficient peer effectively through scaffolding. They learn not only by the repetition of sounds they receive, instead, they develop rules and prove their assumptions to figure out for themselves.

There is some list of characteristics of children, as follows [12-13]:

\section{They are learning by doing}

2. They can talk about what they have done and hear

3. They understand the situation more quickly

4. They are often happy, playing, and working alone.

5. Children learn best when they are motivated by being interested in the activities which are relevant to them

6. They need to be safe and secure

7. They have a short concentration span
8. They need hands-on, concrete experiences in order to learn effectively

9. They also need practical contexts and concrete references in order to understand new learning

10. They need multi-sensory experiences

11. Their first language is still developing rapidly

12. Most are in the first stages of learning to read

13. They need and enjoy lots of repetition (this particularly at story time, long time and when they are in the process of mastering new skills.)

14. Much language development in both first and second languages is inner (i.e. they understand more than they say)

15. They may not be ready for certain structures and complexities in either first or second language

The researcher concludes that very young learners still develop with unique characteristics. The young learners learn as they play so the teacher can draw attention to the characteristics of very young learners, so it easier to decides which techniques relevant to teaching. The teacher should use teaching techniques that appropriate to their level.

\section{B. Teaching Techniques to Very Young Learner}

Children love to play. They love to be active and engage with others as the social beings. The school has been considered the serious time when it comes to learning process which is opposite of play. However, children are still developing. They learn as they play. The very young learner is about 3-6 years old. Children's development is a process where the attitude of children changes from not mature to be mature, from simple to be complex, and a human's evolution process from dependence to be independence one. A very young learner is a child that has many potentials. Its potentials stimulated and developed to make the children's personality will develop with maximum way. As Halliwell [14] said about teaching very young learners as below:

"We are obviously not talking about classrooms where children spend all their time sitting still in rows and talking only to the teacher"

Therefore, the teacher responsible for provides variety of experiences through activities for children at school without getting them bored. Children are creative and want to be active so it is better to make use of their imagination and energy in games, songs, drawing pictures or puzzle-like activities.

The teacher has an important role in the classroom to choose the right method of teaching for very young learners. There are so many methods and approaches that can be used. For examples using Total Physical Response (TPR) by Asher as a potential technique to teach English, especially for very young learners [15]. The method keeps children active in the learning process, as students learn the language linking with physical movement. Very young learners are easily distracted and have very short attention spans. T herefore, it is better to keep in mind that 5 and 10 minutes of activities are best to engage them in learning.

The researcher concludes that to choose the right teaching technique for the very young learner, the teacher 
must adjust the teaching technique with the method, material and also the approach to teach the students. In order to make the students keep focus and they do not get bored.

\section{Kinds of Teaching Technique for Very Young Learners}

According to Saracho \& Spodek, every child has a difference of learning style [16]. There is a child that good in learning with auto-visual way, the other like to learn with their sense or feel, and also there are children that like to use both of that to learn. The teacher must be sensitive toward a variety of student's learning style. Although all children have the same experiences in the classroom that can give them different sense. It is the reason why a teacher should make a good teaching technique in the classroom. The teacher cannot develop the children knowledge with one technique.

The technique chosen for very young learners should be supported by suitable method and activities which will attract the attention of young children. For example, the teacher wants to teach about language, Language needs to have a function in a social environment rather than a set of grammar rules, so communication should take place to be able to master it [17]. We can use the Communicative Language Teaching (CLT) as the method which is related to the reallife language activities introduced by Hymes [17]. According to Richards \& Rodgers [18], in CLT, contextualization of the target language, effective communication, and comprehensible pronunciation are used quite often. Children interact with other learners so that they can share their language skills with each other in playing games, sing songs, etc.

According to Susilawati [19], educative games can be a very effective way for very young learners to learn subject matter and to have fun in teaching and learning process. Games an incorrect setting can be non-threatening and enjoyable for the students. Meanwhile, the main object of tour or field trip technique is a good interactive tour can take very young learner into a new level of understanding in a specific object or area. Besides skill is a series of mini learning situation to facilitate or help the students to learn in individual or to be part of the team.

The presentation also serves as an excellent teaching technique for students. It can be used to teach the subject matter to the students. Media are any devices that assist the teacher to transmit to a learner fact, skills, attitudes, knowledge and appreciation of additional materials used when using a particular teaching method to make easy in learning. There are four types of media which are print, visual, audio, audio-visual. Then role-playing technique sets up situation (or scenarios) that are close to the real situation as possible and allow to children to play the roles.

The children who are doing something retain 75 to 90 percent of what they learn as compared to 5 to 10 percent of what they hear or 20 to 30 percent of what they see. Teaching technique is commonly used by teacher or lecture, the guided discussion technique etc. creative teaching technique enhances the benefits of active learning. Some creative techniques include drama or role-play, music, simulations, and learning games. The techniques can be applied in the classroom, which can bring the student to a real-life situation. The teaching technique can be combined with the learning activities which are presented in enjoyable and relax situations. There are seven techniques that researcher going to use as the guideline in doing this study. They are disciplinary technique, using media picture, song, real object, giving the reward, Show and tell, games and playing.

\section{1) Disciplinary Technique}

According to Walters and Sally, classroom discipline is the specific management of students' behavior [20]. Discipline deal with how people behave. It is about in impulse management and self-control. Lewis stated that primary teachers frequently encourage their pupil to participate in rule formations, hint that behavior should improve, praise and rewind appropriate behavior [21]. The teacher can discuss with the students about the inappropriateness of misbehavior and punish students who misbehave, increasing the level of consequence if students argue or repeat the misbehavior.

Strong stated that most effective teachers admit that rules, procedures, and routines take precedence over academic lesson during the first week of school, noting that organization takes a considerable investment of time at first but has tremendous payback benefits [22]. What the teachers do in the first days of school will determine the success or failure for the rest of the school years. The teacher needs to be discipline, firm, and consistency.

Additionally, discipline is absolutely necessary for instilling a sense of responsibility and maturity in the students [20]. To manage the students' behavior, a teacher should apply the disciplinary technique in the classroom. Very young learners need to be well organized by the teacher because they love the play and do everything that they want to do. They cannot control their self, without rules or procedures for discipline in the classroom; the learning process will be less effective.

From the statements above the researcher concludes that disciplinary technique is a technique of teaching that treats students to liar to be disciplined and responsible person. This technique can be applied by the teacher to organize the students' behavior and classroom management in order to make the learning process effective. In teaching English vocabulary, it will be good if the teacher using English when the teacher commands the students because it will be repeated every day. So, the students will remember and understood the words.

\section{2) Using Media}

Teaching language needs good and interesting media, especially teaching English. Media used in the teachinglearning activity will keep the learner focus on the teacher, thus the classroom will be on teacher's control. The media used should be effective and interesting. Suyanto said that the use of effective and interesting media in teaching can help the students understand the material easily [23]. According to Zvavanhu, there are four types of media which are print, visual, audio, and audiovisual [4]. One of the general type of media that usual to used is picture media (print). There are kinds of media picture that can be used in the teaching-learning English to very young learners, they are flashcards, the picture of the diagram, poster, etc. For another example kind of teaching, media are video, whiteboard, films, overhead projection, data display, etc. The creativity of the teacher will give functions to the media used. 


\section{3) Using Song}

The song is also used as media in teaching. The song is a kind of audio, visual and kinesthetic activities. The song can be useful in teaching children since almost every child likes singing. The teacher who is aware of this can introduce new enters of new structures. Ledbetter stated that teacher is faced whit two main issues: how to get students motivated to learn and how to keep them focused on what will be taught [25]. Very young learners appear that music is the key to both of these issues. The very young learner is naturally musical; that is, they love to listen to music and they enjoy singing. Therefore seems consequential that music should be used to achieve and maintain a child's interest in almost all subject areas.

Moreover, Cakir explained that songs contain words and expressions of high frequency and offer repetition [26]. The action rhymes of song captivate very young learners and help the teacher to convert children's natural energy and enthusiasm into meaningful learning experiences. Action rhymes also help the very young learners to associate word and phrases with meaning. It also seems that students pay more attention to the lesson that is connected with something relevant to their lives and song provides an excellent bridge. By using the song, they will remember whole rhymes that contain with the purposed lesson easily. In this technique, the teacher must lead and teach how to pronounce the words of song lyrics.

According to Ara, music is a source of motivation, interest, and enjoyment, it is much easier for children to imitate and remember than words which are just 'spoken' [27]. Again, a song or a chant can be used very effectively to teach children. The criteria for classroom song are: first, the music must have an easy to memorize melody line, suitable for either unison singing by the whole class or solo. Second, the language must closely approximate normal speech style. Third, the music, theme, and language should be appropriate to the age of the learners.

\section{4) Using Real Object}

According to Soames, in the TEFL classroom, the word realia means using real items found in everyday life as an aid to teaching English [28]. Using real object helps to make memorable English lessons by creating a link between the objects and the word or phrase they represent.

It is possible to use the real object to teach almost any subject. The advantages of using the real object as English teachers is that it stimulate the students' mind and it is one way for encouraging creativity by involving students' senses. The main point of it advantages is that it is not only limited by student imagination. Elicitation becomes much easier and holding up the object with a raised eyebrow will usually result in the desired word being spoken. They can function to help learners in remembering vocabulary better because our memory for objects and pictures is very reliable [29].

Real object breathes life into the new vocabulary and the chances of the students remembering the new words you have taught them increases. Take the word biscuit: the probability of remembering it becomes much higher after experiencing the taste, touch, and smell of the object. Real object does not have to be limited to food or drink. Timetables, tickets, newspapers, clothes, etc. In fact, any object you can think of can be used as a teaching aid.
Bringing real object into your lessons takes some of the attention and pressure off you by concentrating the students' minds on the object and word in question.

Soames mentioned that using realia or real object for learning vocabulary/grammar [28]. It is limited for bringing real objects into classroom for every single word that you wish to teach. Some words will lend themselves better without using realia. Remember, realia can be used indirectly as a tool for teaching grammar. For example, items of food and drink are perfect for teaching uncountable and countable nouns. This kind of teaching technique is very helpful for the teacher and students. This technique can avoid the misunderstanding about the word and the object that discuss. So students can more focus and understand the teaching and learning process.

\section{5) Giving Reward}

Giving Reward is any form of respect by the teacher that makes students happy because the good results that have been achieved in the educational process. The purpose of the reward is a motivation for the students to be able to do the commendable and try to improve achievement. Giving a reward is one of the teaching techniques. So, the purpose of providing the reward is to make students feel happy because of what his or her job awarded. Generally, children learn that the work or actions which cause he got that reward. Besides, giving reward intent is to bring children to become more active efforts to correct or improve his achievements.

According to Alma [30], purpose of the reward are 1) improve students' attention, 2) expedite or facilitate the learning process, 3) generate and maintain motivation, 4) control and changing the attitudes of students were disruptive and lead to a productive learning behavior, 5) develop and organize themselves in learning, and 6) direct for a good way of thinking. Indrakusuma stated that, there are many kinds of rewards that we can give to students [31]. But, the rewards are generally of four types, there are praise, respect, gifts and sign of appreciation/symbolic rewards.

\section{6) Show and Tell}

Selecting a technique in teaching vocabulary was necessary to increase student language ability. Show and tell is the technique of the teacher to develop the student's listening ability as the object or print, then repeating a word or sentence after teacher. Show and tell technique is one of the techniques that is enabled to increase students' language ability in vocabulary mastery. In this technique students are taught to memorize words by sight, the student learns carefully and draws on picture clues and keywords, the students are encouraged to glean the meaning of unfamiliar words from the context.

Show and tell the technique commonly used by the young learner to learn to read words letter by letter. But for students of kindergarten, they are only given a lighter treatment. Typically students will be shown the word is used as a symbol of the object for students of kindergarten is the very young learner who cannot read. They only see the word as a symbol and cannot spell the letter by letter. This technique is used to introduce a form and mention of an object. In vocabulary learning of this technique is desperately needed in order to facilitate the child in memorizing the pronunciation of a word, where the Indonesian people themselves differ somewhat in the English language learning 
as a way of spelling and writing in a way different from the way Indonesian spelling. This technique can be combined with other techniques that use pictures or other media. It is the kind of teaching technique that important in process of transferring knowledge. It can make students deep in remembering the vocabulary.

\section{7) Games and Playing}

According to Reilly and Ward, very young learners are children between the ages of 3 and 6 who have not begun elementary school [32]. It can be suggested that games are a part of very young learners live. Very young learners are easily distracted and have very short attention spans; therefore, it is better to keep in mind that 5 and 10 minutes activities are best to engage them in learning and after that, they will start to bore and tired. Therefore, games are one of the activities of teaching and learning which is believed to be the best technique of teaching and learning is through games. Games help and encourage many sustain in their interest and work.

Playing games is one of motivation way of teaching very young learners. Scannel stated that games are motivating, since they create the contact for their pay, and lead to social intellectual involvement [33]. In selecting the kinds of games, the activities should contribute to the furthering aims of the lesson and it should maintain the interest of all the students who are playing.

Yolageldili and Arikan mentioned that games are enjoyable and make the learning process easier [34]. Games are full of fun which leads to successful learning. In many games, learners are required to cooperate to achieve the goal, and most of the learners enjoy cooperation and social instruction. It is believed that when cooperation and possible. The competition which is associated with games plays a crucial role in the nature of the game requires. Learners are excited by competition because the question of who will win or lose reminds unanswered until the game is over.

Games involve the rule which must be followed, competition between individual or team, and determination of a winner. In terms of players are a part of game plans, cooperative learning, as well as competition, can result. He gives suggestion in using games as; the teacher should start by deciding whether the game will be the advance achievement of learning objective. McCallum suggests that the teacher should organize the game before the instruction [35]. The teacher should find ways to adapt games to the capabilities of students and trainees. He/she should begin the games with simple but interesting activities.

As mentioned before, children like to do something or playing. Games can make children fun, so it is the useful technique in teaching for the very young learner. In this case, the teacher should be careful enough to make the games enjoyed by the children and at the teacher able to decide which one is best for the students' need. From the statements above the researcher concluded that there are some of the common teaching technique that can be used by a teacher to teach very young learner. Those are disciplinary technique, using media picture, song, using a real object, giving the reward, questioning, playing games and playing. The teacher can use those technique base on the purpose of learning. those techniques are really important to build or rebuild students' motivation in learning. The teacher should be cleaver to think when the teacher can use this technique in teaching and learning process.

\section{Concept of Vocabulary}

Vocabulary is stock of words used by people or by a particular class or person. Vocabulary is acquired incidentally through indirect exposure to words and intentionally through explicit instruction in specific words and word-learning strategies. In the same hand, Kamil \& Hiebert stated that vocabulary is generically defined as the knowledge of words and word meanings [36]. Moreover, vocabulary refers to a list or set of words for a particular language or might use by an individual speaker of a language. It means that vocabulary as the words of a certain language which are used by language speaker in using language. More specifically, vocabulary refers to the kind of words that students must know to increase their comprehension through reading text. Vocabulary building is vital to make progress in foreign language learning. Thus, it's important to introduce vocabulary learning strategies for students. While, there are four types of vocabulary: oral, print, receptive, and productive [36]. For the purpose to enhance their comprehension, fluency, and language achievement.

\section{E. The concept of BCCT (Beyond Centers and Circle Time)}

According to Baddong [37], the purposes of the BCCT model are:

1. To improve services to children's learning experiences in greater depth by giving freedom to explore in each center.

2. To train children to be more independent because it does not depend on the class teacher alone, but will be directed to undertake activities with other teachers, especially as teachers centers

3. The learning process is expected to take place naturally in the form of children's activities work experience, not just a transfer of knowledge from teacher to child.

4. In this context, children can understand what it means to learn, what the benefits are, the status of what they are and how achievement, they realize that what they learn will be useful for their lives later.

5. Children can position themselves requiring a provision for later life, in this case, the teacher centers served as a director and mentor or aspirator.

Center learning model created depend on the room size. If the room is big, the teacher will combine every center to one classroom. But if the room is small, it means every center will have one classroom.

\section{RESEARCH METHOD}

According to Milan in Syamsirani [38], research design is the investigation of structure and plan that is used to obtain empirical evidence. Yerkes [39] stated that descriptive study is the act, process, or technique of study to describe representation a figure. Besides, this research is also qualitative due it presents an analysis of the data. Qualitative 
research is the resource of description widely, sturdily, and includes the explanation about processes which happened in a place or condition replying question of research. The design of this research is descriptive study because the researcher wants to describe teaching techniques used by the teacher in teaching English vocabulary of young children B class Al- Azhar Kindergarten Samarinda with BCCT in the 2016/2017 Academic Year.

Arikunto stated that the subject of the research is a source of data; it can be a person, place or paper [41]. The subject of this research were the teachers of B class Al-Azhar Syifa Budi Kindergarten Samarinda. There are 4 teachers whose teaching in a center for each teacher. This selection based on consideration. The researcher chose teachers of Class B because the researcher thinks the students of that class had the mature concept in their mind. So, it's easy to see the real feedback from the students.

Data analysis is conducted along with the process of data collection, it is analyzed appropriately with the procedures of data analysis interactive model. There are three concurrent flows activities; data collection, data reduction, data display and drawing the conclusion.

\section{RESUlt AND DisCUSSION}

\section{A. The Findings of Teaching Techniques}

The researcher is going to describe and explore the teaching techniques that teachers used in teaching English Vocabulary. There were seven techniques that the researcher used as the guidelines in observation. There were disciplinary (D), media (M), song (S), real object (RO), show and tell (ST), games and playing (GP), giving the reward (GR).

The percentage of teaching techniques used by teachers in teaching English vocabulary for 5-6 years old students of Al-Azhar Syifa Budi Kindergarten Samarinda based on the BCCT learning model in the 2016/2017 academic year. The data showed that all teaching techniques were used by teachers with differences level of percentage. The most frequent techniques used by teachers are media (26.5\%), then followed by disciplinary (23\%), giving the reward $(20 \%)$, show and tell $(15.5 \%)$, song $(6 \%)$, real object $(4.5 \%)$, games and playing $(4.5 \%)$.

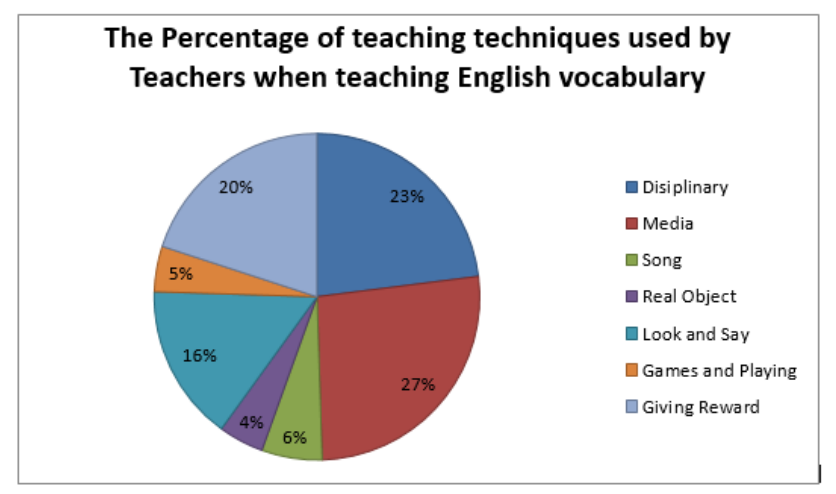

Fig. 1. The percentage of teaching techniques used by teachers in teaching English

\section{B. Descriptions of teaching techniques used by teachers when teaching English Vocabulary in B class}

In this section, the findings related to the analysis of the teaching techniques used by the teacher in the teaching and learning process. Descriptions are aimed to answer the research question; "What are teaching techniques used by teachers in teaching English vocabulary for 5-6 years old students of Al-Azhar Syifa Budi Kindergarten Samarinda based on BCCT learning model in the 2016/2017 academic year?" After the researcher conducted the study, the research found and classified the teaching techniques used by Teachers in seven techniques same as the researcher's guidelines. Those were presented as follows:

\section{1) Disciplinary Technique}

The percentages of disciplinary techniques is $23 \%$. Teacher applied the disciplinary techniques since the first meeting with her students. She tried to manage the students first before they have come into the classroom. She introduced rules, procedures or routines that she will apply in the classroom. In teaching and learning process, the teacher applied the technique of disciplinary to her students. Before the teacher let her students come to the classroom. The teacher asked the students to do their routines and tell the students about the rules that she was going to do in the classroom. She hoped that by using rules in teaching and learning process, the students would be manageable and discipline.

\section{2) Using Media Technique}

The media that teacher used by teachers included pictures, flashcard, papers, the teacher also used video in teaching. In this research, this technique has been used by teacher $26.5 \%$. It was the technique which teacher almost used in the classroom. This technique has a huge influence on the students to develop their knowledge. This technique included so many activities to introduce, explain and also to test the student's knowledge.

The teacher used the flashcards was not only to inform her students about the vocabularies but also in remembering the pictures and also the explanations. The teacher used the video as media in teaching and learning process, where that video was related to the topic. The teacher did this technique to show the students the real examples and explanation. The teacher also used this technique to emphasize the vocabularies to make the concept in students brain before they did the other activities with a related topic.

\section{3) Using Song Technique}

In this research, the teacher used the technique of using song only $6 \%$. From the whole research time, this technique only appeared 4 times. Although the students like to sing, it does not mean the teacher could do it every day to motivate their students in this way, because this could make students bored. By using this technique, the teacher could be relaxing the students and made them happy. Rhymes and chants are useful in other areas of learning as well. Children love rhymes and chants and like to repeat them again and again. Rhymes and chants helped students in the foreign language by helping them to remember word and sentences. This technique was used after the teacher told the students about the topic and vocabularies.

4) Real Object Technique 
The teacher used this technique to remain the basic concept and experiences that students have. The teacher used the real object to limit the students' imaginations. The real object can be used indirectly as a tool for teaching grammar. For example:

Teacher: Semuanya lihat Asri ya! Ini apanya? (The teacher pointed Asri's hair)

Students: Rambut.

Teacher: Bahasa Inggrisnya? Nazar: Hair

Teacher: Ok, good! This is for you! (Gave the stamp)

Teacher: What is this? (The teacher pointed eyebrow)

Chelsea: Eyebrow

Teacher: Good Chelsea! This is for you!

\section{5) Show and Tell Technique}

The percentage of show and tell technique is $15.5 \%$. Teacher applied this technique to support the explanation. This technique used by the teacher to train the pronunciations of the students. So, the students are able to speak with those vocabularies easily. Besides, this technique would make the students memorize the vocabularies and remember the thing. The teacher also used this technique not only with the point the thing or stuff but also by showing how the vocabulary is done by people. In this research, the teacher used body language and hands gesture to lead what the vocabularies mean. In this case, the teacher used many hands gesture to do something for her face. The teacher did it to tell the students what vocabularies mean and how people do it in daily life.

\section{6) Games and Playing Technique}

These techniques of teaching brought the light to the teachers. They built up a good relationship with the students. They began to be the spirit, excited and competitive. The teacher was able to take the students heart through games and playing. In this technique, the teacher also can evaluate the students about rising teaching target.

\section{7) Giving Reward Technique}

Giving reward was the frequent technique that teacher used after media. Give reward has a percentage of $20 \%$. Teachers always used this technique to appreciate students' achievement on learning or when they did something good. They also tried to get students attention by using this technique. In this research teachers raised it by doing some kinds of reward:

The teacher also gave many stamps to her students where they were active in teaching and learning process. It made the other students be spirit and competitive. The teacher often gave candies when her students can answer the question perfectly. The teacher realized that her students got less appreciate and attention from their parents, what they needed are some people who cared about them. The students were really happy in learning because the teacher always appreciated their work even just for a small thing.

In teaching students at the school, the teacher should build good character to their students. First is they should grow interested in learning and contribute to class activities. Teachers also should make their students feel happy and enjoy in the classroom. They cannot feel depressed for some troubles in the class. Any activities that they did in the classroom should create their spirit and competitive energy with the other. So, they will grow as the best they were being. Second, in teaching the students, the teacher should develop students' language. In the golden age time, it is really important to adjust the language with brain concepts which referring to anything that they should know and learn.

B Class' teachers of Al-Azhar Syifa Budi Kindergarten Samarinda used various techniques in teaching English vocabulary. Based on the research findings from the research data, there are seven techniques that the teacher used to reach the goal of teaching. The techniques involved: disciplinary (D), media (M), song (S), real object (RO), show and tell (ST), games and playing (GP), giving the reward (GR). In applying the teaching techniques, teachers considered the characteristic of their students first. This is supported by Westwood stated that the appropriateness and efficiency of a particular teaching technique can be considered in relation to the type of learning, it is supposed to bring about and in relation to characteristics of the learners.

The disciplinary technique was the first technique that they used. This was the first phase of teaching English as the foreign language that they should learn. the teachers thought that creating procedures or daily routines for their classroom were the most important point that teacher and students should do before they started to teaching and learning process. This idea is supported by Emmer, Evertson, and Worsham stated that most effective teachers admit that rules, procedures, and routines take precedence over academic lesson during the opening time [43]. The teacher also used rules in teaching and learning process. Students who did not follow the rules would get a punishment, but here the punishment just did to make them more careful with target learning.

The data showed that teachers also involved the use of media and the other techniques to explain the materials. It means there are some special techniques that teachers used in teaching and learning process. According to Zvavanhu, there are four types of media which are; print, visual, audio, and audiovisual [24]. Media that teachers used in Al-Azhar Syifa Budi Kindergarten school are pictures of object, flashcards, video etc. beside the audio media includes in using song part. These media has an important role in transferring knowledge. Where teacher should be added or connected the knowledge that students have. One of the general type of media than usual to used is media picture (print) as stated Hernandez \& Gomes [43].

To help the students in understanding the material easier, the teacher used the song technique. Actually, song is one of the media in teaching which could be used as a valuable teaching and learning tool as songs help learners improve their listening skills and pronunciation [6]. Commonly, the teacher used a song followed by music and some hands and body gestures. Students were not difficult to remember the words, but they were difficult to relate the word with the translation. By singing, students felt easier to train their pronunciation because most children enjoy singing and usually respond well to using songs in the classroom.

Songs can provide the opportunity for vocabulary practice. They are usually based around a theme or topic that can provide the context for vocabulary learning. In this case, teachers used the songs 'Family Fingers', 'we are a happy family, 'Singing the Family' for example, could be used to review family parts or the song ' I wash My Body' might be 
useful for reviewing body parts. The children's songs are characterized by monosyllabic words, many of which are frequently repeated. This repetition offers greater exposure to these words and can help to improve vocabulary acquisition.

Games can also be used as a way to review vocabulary and provide the key feature of a drill with the opportunity to sense the working of language as living communication [43]. So the way of the teacher in using this technique was right. The teachers used the technique of the game after the students learned the new vocabularies. It made sure the vocabularies are known and understood by students.

Teachers always appreciated every single student for what they have done. They often said that they were proud of their students' creativity and ability in doing something. For examples, the teacher said 'good job', 'good', 'excellent'. That was in line with Mayesky discovered that students like to feel proud of themselves [44]. Thus, the action taken by teachers to appreciate students' contribution is a wise decision. By knowing students means we understand the high standards and expectations for all of them. Since the teacher was giving her best to appreciate students' work and celebrate students' achievement, students felt pleased and supported by their teacher. As the result, giving rewind technique could create a good relationship between teachers and students.

A teacher should not ask "Siapa nama ayah kalian?' but it should "Who is your father?". A teacher has the same important role in developing students' vocabularies. Therefore the English learning process does not point only to one teacher and English can be more familiar to be used in the school environment. Nothing makes English ruled out. As what has been stated in school motto which is creating human resource who have wide knowledge globally. Language is most needed.

In conclusion, there were seven techniques of teaching English applied by teachers in B class of Al-Azhar Syifa Budi Kindergarten Samarinda. The techniques were disciplinary, media, song, real object, show and tell, games and playing, and also giving the reward. A teacher works together with other teachers. A teacher has the duty to repeat back the vocabulary has been taught before. All the techniques that applied by teachers are effective for their students or very young learners because that way is very fun and interest. The effectiveness can we see from the students' feedback in the classroom. They really enjoyed the learning process.

\section{CONCLUSION}

The result of findings showed that there are seven teaching techniques used by teachers in teaching English vocabulary for 5-6 years old students of Al-Azhar Syifa Budi Kindergarten Samarinda based on BCCT learning model in the 2016/2017 academic year. Those were disciplinary $(23 \%)$, using media $(26 \%)$, using song $(6 \%)$, using real object $(4.5 \%)$, giving reward $(20 \%)$, show and tell $(15,5 \%)$, and games and playing $(4.5 \%)$. The most frequent technique used by teachers was media, then followed by disciplinary, giving reward, show and tell, using song, and for the lowest frequencies are using real object, games and playing with the same percentages. The researcher also found that all of the techniques that teachers used in teaching and learning process are good. All of students interest and connected when teachers transferring the knowledge. However, there were techniques that have the lowest frequency. It do not mean that is the bad techniques than the other techniques. But, it is because those techniques can make them bored if too much used. To teaching English vocabularies in BCCT class, the teacher should work together to maximize absorption in students learning.

\section{REFERENCES}

[1] J. Enever \& J. Moon. New global contexts for teaching primary ELT: change and challenge. In Enever, J., Moon, J. and Raman, U. (eds.) Young learner English language policy and implementation: international perspectives. Reading: Garnet Education, 2009.

[2] M. Paradis. A Neurolinguistic Theory of Bilingualism. John Benjamins Publishing, 2004.

[3] H.D. Brown. An Interactive Approach to Language Pedagogy. New York: Pearson Education, 2005.

[4] K. Sheahan. Methods for classroom instruction, 2008, from: http//www.eHow.html retrieved on September $15^{\text {th }}, 2016$.

[5] K. Nisak. Teaching English to Very Young Learners Using Games, 2011, from: http//www.someeduCenter.com retrieve on September $25^{\text {th }}, 2016$

[6] L. Cameron. Teaching English to Young Learner. Cambridge: University Press, 2001.

[7] H. Sjamsir. The Influence of TPR, GTM Methods and Linguistic Intelligence towards the Learning Outcomes In English DAP Based (An Experimental Study at the Students of the Second Grade of SDN Samarinda, East Borneo) (Published: English Language and Literature $\quad$ Review Journal). https://ideas.repec.org/a/arp/ellrar/2018p58-61.html, 2017

[8] T. Musfiroh. Cerdas Melalui Bermain. Jakarta: Grasindo, 2008.

[9] Risna. The Correlation between Early Childhood Education with Cognitive Development of Preschool Aged Children in Tinjomoyo Village Banyumanik Sub district Semarang City. Semarang: Universitas Diponegoro, 2009.

[10] J. Piaget. The science of education and the psychology of the child. New York: Oxford, 1970.

[11] L. Vygotsky. Thought and language. Cambridge, MA: MIT Press, 1962

[12] W.A. Scott \& L.H. Ytreberg. Teaching English to Children.Longman New York, 1993.

[13] Isjoni. Pembelajaran Kooperatif. Jakarta: Pustaka Pelajar, 2013

[14] S. Halliwell, S. Teaching English in the primary classroom. U.K.: Longman, 1992.

[15] J. Asher. Learning Another Language through Actions: The Complete Teacher's Guidebook, 2009.

[16] O. N. Saracho \& B. Spodek. Oracy: Social facets of language learning. New York: Routledge, 2008.

[17] D. Hymes. Foundations in Sociolingustics. Philadelphia: University of PennyslvaniaPress, 1974.

[18] J.C. Richards \& T. S. Rodgers.Approaches and methods in language teaching. USA: Cambridge University Press, 2001.

[19] T. Susilawati. The Teaching Techniques Used By Ron Clark In The Ron Clark Story Movie. Samarinda: Mulawarman University, 2012.

[20] J. Walters \& F. Sally. Managing Classroom Behavior and Discipline. U.S.A: Shell Education, 2007.

[21] Lewis, R. Understanding Pupil Behaviour. New York: ACER Press, 2009.

[22] J.H. Stronge. Handbook for Qualities of Effective Teacher. Alexandria: ASCD, 2004.

[23] K.K.E. Suyanto. English for Young Learners. Jakarta: PT. Bumi Aksara, 2007

[24] Zvavanhu. Type of Media Used inTeaching and Learning for Its Conductive Environment, 2010. from http://zvavanhu.mywapblog.com retrieved on September 17th, 2016.

[25] J. Ledbetter. Music: Key of Learning., 2001, from: http//www.Songforteaching.com/ledbetter/key/htm retrieved on September 15 th, 2016 
[26] A. Cakir. Musical activities for Children of EFL. The internet TESL Jurnal, $\quad 5, \quad 2002, \quad$ from:http//www.itselj.org/lesson/CakirMusicalActivities.html retrieved on August 17th, 2016.

[27] S. Ara. Use if Song, Rymes, and Games in Teaching English. The Dhaka University jurnal of Linguistics Vol.2 No.3, 2009.

[28] C. Soames. Teaching Vocabulary with Real or Realia object, 2014. http://www.eslteachersboard.com retrieved on September 15th, 2016.

[29] R. Gairns \& S. Redman. Working With Words. Cambridge: CUP, 1986

[30] B. Alma. Guru Profesional Menguasai Metode dan Terampil Belajar, Bandung: Alfabeta, 2008.

[31] A.D. Indrakusuma. Pengantar Ilmu Pendidikan, Surabaya: Usaha Nasional, 1973

[32] V. Reilly \& S.M. Ward.Very young learners. Hong Kong: Oxford University Press, 1997.

[33] Scannel. The Complete Games Trainer Play. New York: McGraw Hill, 2004.

[34] G. Yolageldili \& A. Arikan. The effectiveness of Using Games in Teaching Grammar to Young Learner, 2011. From: http://Ilkoqretimonline.org retrieved September 17th, 2016.

[35] G.P. McCallum. 101 Word Games for Students of English as a Second of Foreign Language. Oxford: Oxford University Press, 2000.

[36] M.L. Kamil \& E.H. Hiebert. Teaching and learning vocabulary: Perspectives and persistent issues. In E.H. Hiebert and M.L. Kamil (eds.), Teaching and learning vocabulary: Bringing research to practice. Mahwah, NJ: Erlbaum, 2005.

[37] R. Baddong. Model Pembelajaran Sentra Bahan Alam Dalam Pengembangan Kecerdasan Naturalis Pada Anak Usia Dini di Taman Kanak-kanak Tunas Mekar Bontang. Samarinda: Mulawarman University, 2016.

[38] F. Syamsirani. The effect of using the picture in developing the ability of the first grade students in SMPN 9 Samarinda. Samarinda: college of English education of Mulawarman university, 2009.

[39] D. Yerkes. Webster's Encyclopedic Unabridged Dictionary of The English Language. New York. Portland House, 1989.

[40] S. Arikunto. Metodologi Penelitian Praktik. Bandung: Tarsito, 1998.

[41] P. Westwood. What Teachers need to Know about Teaching Methods. Camberwell, Vic: ACER Press, 2008.

[42] E.T. Emmer, C.M. Evertson, \& M.E. Worsham. Classroom management for secondary teachers(6th ed.). Boston: Allyn and Bacon, 2003.

[43] R.I.T. Hernandez \& C.L.L. Gomez. Ways to teach EFL vocabulary to children. Spanyol: Universidad Veracruzana, 2011

[44] M. Mayesky. Creative activities for young children: Delmar Cengage Learning. Newyork: Clifton Park, 2009. 